\title{
Pemanfaatan Internet Of Things Dalam Sistem Peringatan Dini Pada Smart Village
}

\author{
Dony Susandi ${ }^{1 *}$, Harun Sujadi ${ }^{2}$, dan Wildan Rohmanudin ${ }^{3}$ \\ ${ }^{1}$ Prodi Informatika, Fakultas Teknik, Universitas Majalengka \\ Jalan K.H.abdul Halim No. 103 Majalengka Kota Majalengka45418 \\ e-mail: dys@unma.ac.id, harunsujadi@unma.ac.id, wrohmanudin@gmail.com,
}

\begin{abstract}
Abstrak - Smart village merupakan sebuah ekosistem yang melibatkan pemerintahan, industri, akademisi ataupun masyarakat untuk mejadikan desa lebih baik. Konsep smart village diharapkan mampu membuat masyarakat desa dapat mengetahui permasalahan disekitar daerahnya. Dalam 10 tahun terakhir ini permasalahan yang timbul dan mengalami peningkatan yaitu pada sektor bencana, selain itu permasalahan yang timbul adalah kriminalitas, bahwa pada tahun 2018 indexs kejahatan diindonesia mencapai peringkat 68 dari 147 negara. Dalam hal ini Indonesia khususnya didaerah pedesaan perlu adanya sebuah sistem yang dapat memberitahukan peringatan dini bencana dan kriminalitas dengan real time berbasis Internet of Things, dimana sistem ini akan saling terhubung antara website pemerintah desa dengan warga. Early warning system ini dibangun menggunakan metode prototyping, dimana metode ini dimulai dengan mengidentifikasi masalah yang terjadi dilapangan, lalu desain sistem, pengujian dan implementasi. Early warning System ini pula dibangun dengan sebuah tiang yang dilengkapi dengan sensor kebakaran, gempa, kualitas udara, panic button, lampu otomatis dan kamera monitoring system untuk memonitor keadaan sekitar layaknya CCTV. Hasil dari input-an pada sensor akan diproses oleh mikrokontroller dan dikirim pada webservice untuk diteruskan pada smartphone.
\end{abstract}

Kata kunci: Smart Village, Sistem Peringatan Dini, Internet of Things, Bencana, Kriminal.

\section{Pendahuluan}

Perkembangan jaringan internet yang sedang populer pada saat ini adalah Internet of Things [8]. Merupakan bagian dari bidang ilmu dalam jaringan yang segala aktifitasnya terintegrasi dan saling berinteraksi dengan memanfaatkan koneksi internet. hal ini di buktikan dari semakin berkembangnya penggunaan internet di dunia khususnya di Indonesia. Menurut Hootsouite dan we are social pengguna internet di Indonesia sudah mencapai 150 juta penduduk meningkat dari tahun lalu sebanyak 143 juta penduduk dan alat yang digunakan untuk mengakses internet tersebut 60 persen smartphone 22 persen laptop dan komputer 8 persen tablet yang artinya penyampaian informasi dan komunikasi lebih banyak di akses dalam genggaman atau smartphone di banding alat elektronik lainya [1]. Sistem Peringatan Dini (Early Warning System) adalah serangkaian sistem yang berfungsi untuk memberitahukan terjadinya kejadian alam, Sistem peringatan dini ini akan memberitahukan terkait bencana yang akan terjadi atau kejadian alam lainnya. Peringatan dini pada masyarakat atas bencana merupakan tindakan memberikan informasi dengan bahasa yang mudah dicerna oleh masyarakat. Dalam keadaan kritis, secara umum peringatan dini yang merupakan penyampaian informasi tersebut diwujudkan dalam bentuk sirine, kentongan dan lain sebagainya. [2]. Di Indonesia saat ini adalah bencana, menurut data statistik BNPB (Badan Nasional Penanggulangan Bencana) 10 tahun terakhir menunjukan bahwa pada tahun 2018 terjadinya peningkatan jumlah bencana di Indonesia yang didominasi dengan kebakaran.

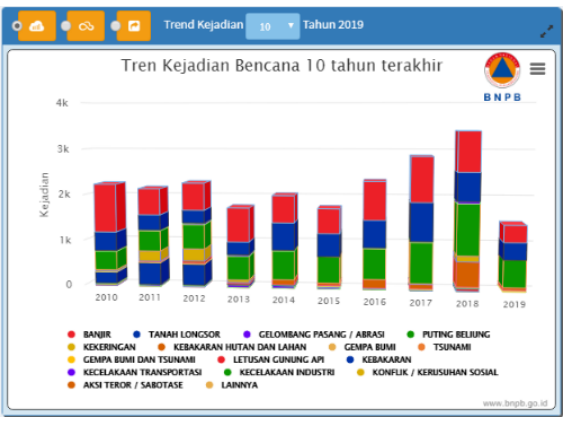

Gambar 1.1 Bencana di Indonesia

\section{Tinjauan Pustaka}

Penelitian ini didasari dari pemikiran bahwa pengguna internet semakin bertambah seiring perkembanagn teknologi yang sangat cepat. Memungkinkan untuk memanfaatkan tekonolgi. Dalam penelitian kali ini internet 
of things digunakan untuk menghubungkan software dan hardware yang bertujuan untuk menciptakan teknologi baru yang sifatnya memudahkan manusia.

\subsection{Internet of Things}

Internet of Things adalah sebuah konsep yang digunakan untuk menghubungkan benda benda melalui sebuah jaringan internet sehingga memudahkan manusia ketika berinteraksi dengan sebuah benda atau mesin. [4]

\subsection{Bencana}

Definisi Bencana menurut Undang-undang Nomor 24 Tahun 2007 Tentang Penanggulangan Bencana menyebutkan definisi bencana sebagai berikut: Bencana adalah peristiwa atau rangkaian peristiwa yang mengancam dan mengganggu kehidupan dan penghidupan masyarakat yang disebabkan, baik oleh faktor alam dan/atau faktor nonalam maupun faktor manusia sehingga mengakibatkan timbulnya korban jiwa manusia, kerusakan lingkungan, kerugian harta benda, dan dampak psikologis [5][9]

\subsection{Early Warning System}

Sistem Peringatan Dini (Early Warning System) adalah serangkaian sistem yang berfungsi untuk memberitahukan terjadinya kejadian alam, Sistem peringatan dini ini akan memberitahukan terkait bencana yang akan terjadi atau kejadian alam lainnya. Peringatan dini pada masyarakat atas bencana merupakan tindakan memberikan informasi dengan bahasa yang mudah dicerna oleh masyarakat.. [6]

\section{Metode Penelitian}

Penelitian ditempuh dengan metode pengembangan Prototyping.

\subsection{Identifikasi Kebutuhan Sistem}

Tahap ini adalah tahap dimana analasis identifikasi kebutuhan sistem, diantaranya terdapat analisis masalah, analisis user atau pengguna, analisis kebutuhan perangkat keras yang akan digunakan dalam penelitian ini, analisis kebutuhan perangkat lunak, dan analisis ketepatan sensor early warning yang berfungsi apakah sensor tersebut berfungsi secara baik atau tidak.

\subsection{Desain Sistem}

Pada Tahap ini melakukan proses visualisasi penggambaran sistem secara keseluruhan menggunakan flowchart, serta perancangan hardware pada sistem yang akan dibangun. Fase desain ini bertujuan untuk memudahkan peneliti didalam menganalisa kebutuhan user pengguna karena telah terdapat visualisasi. Output dari fase ini adalah dokumen desain interface, database dan keseluruhan sistem.

3.2.1. Desain Sistem secara keseluruhan

Desain sistem secara keseluruhan ini berisi tentang perancangan cara kerja sistem, dari mulai solar panel menerima daya sampai dengan selesai. Berikut dibawah ini adalah flowchart dari sistem secara keseluruhan

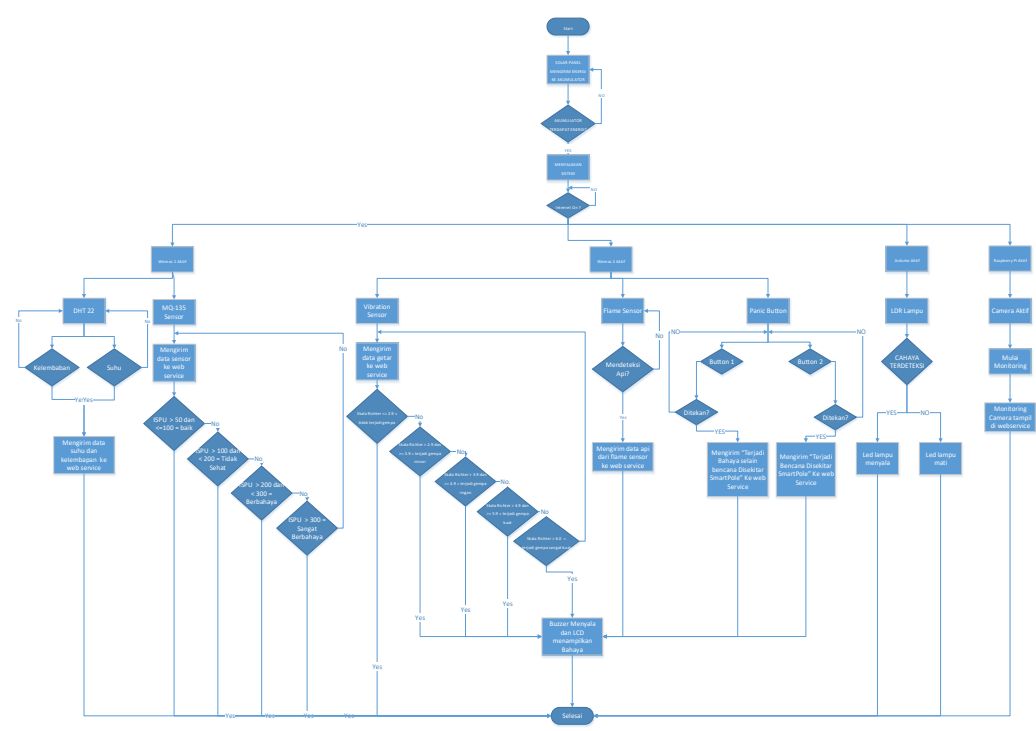

Gambar 3.1 Flowchart sistem keseluruhan

\subsubsection{Perancangan Prototype Early Warning System}

Pada tahap desain early warning system penulis melakukan desain dari prototype early warning system 
yang akan dibuat, perancangan early warning system dilakukan dalam sebuah tiang yang sudah tertanam dalam lokasi. berikut adalah perancangan early warning system yang akan dibangun sekaligus dengan penempatan tiap komponen pada tiang tersebut.

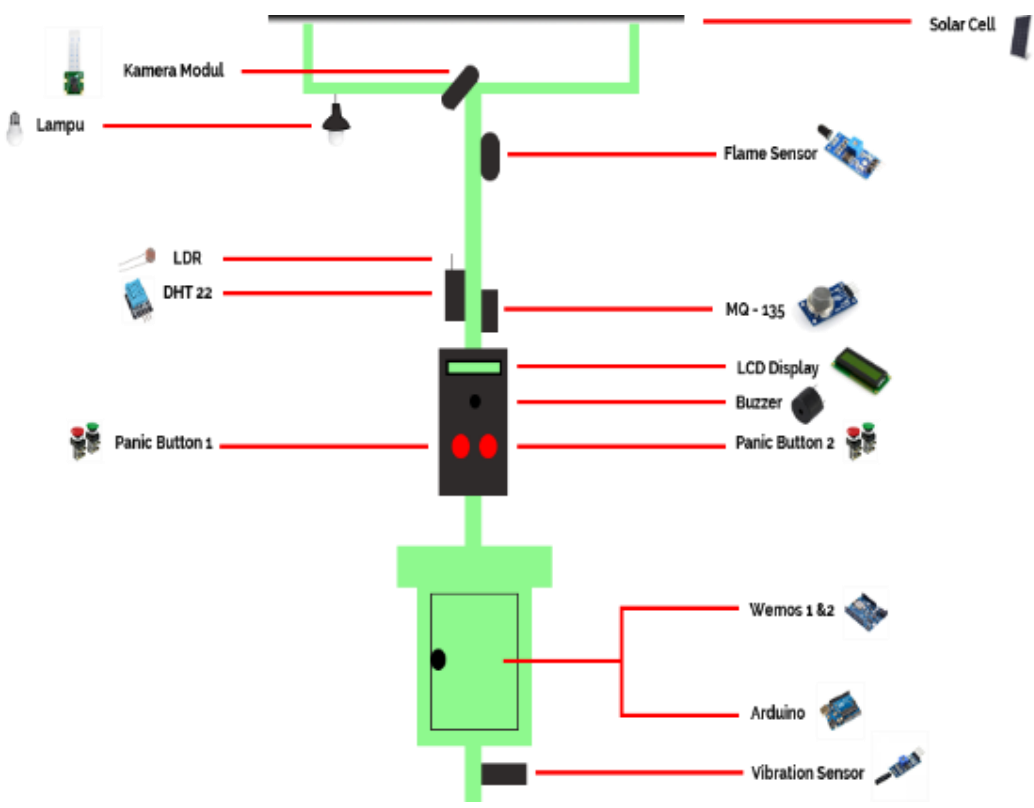

Gambar 3.2. Perancangan Early Warning System

\subsubsection{Perancangan Hardware}

Dalam perancangan perangkat keras ini berisi blok diagram hardware yang digunakan pada early warning system. Blok ini merupakan tahapan awal dalam perancangan sistem. Tahapan ini dilakukan agar memudahkan dalam pengitegrasian perangkat-perangkat keras,baik sebagai input maupun output. Perancangan Hardware dibagi menjadi 3 bagian yaitu perancangan hardware dengan proses wemos (wemos 1 dan 2), perancangan dengan proses Arduino uno R3, serta perancangan dengan pemrosesan Raspberry pi.

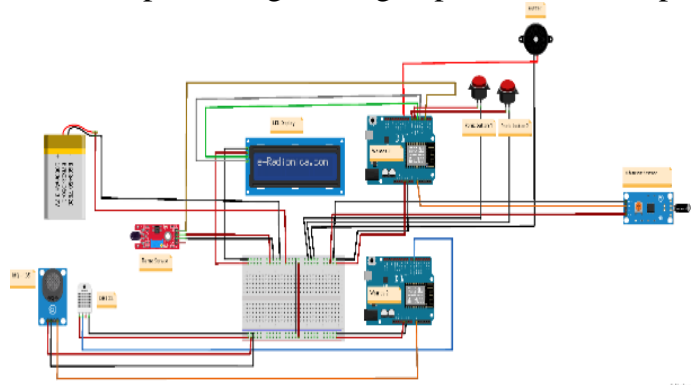

Gambar 3.3 Desain Hardware wemos

Selanjunya yaitu desain hardware pada Arduino, arduino berfungsi sebagai proses LDR, untuk lebih jelasnya dapat dilihat melalui gambar dibawah ini.

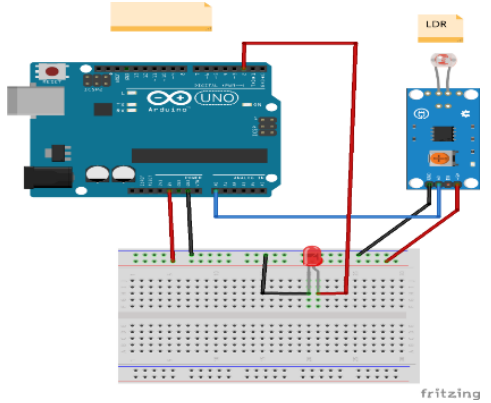

Gambar 3.4 Desain Hardware Arduino 


\subsubsection{Perancangan Software}

Pada perancangan perangkat lunak ini akan dibahas mengenai perangkat lunak yang akan dibangun pada early warning system dengan bahasa pemograman C pada mikrokontroler wemos dan arduino UNO R3 serta bahasa pemrograman python untuk Raspberry Pi. Perancangan perangkat lunak ini berisi tentang perancangan perangkat lunak yang mampu mengitegrasikan keseluruhan sistem secara otomatis, selain itu perancangan perangkat lunak ini dibagi menjadi 4 bagian sesuai dengan mikrokontroler yang digunakan. Untuk lebih jelasnya dapat dilihat melalui gambar dibawah ini

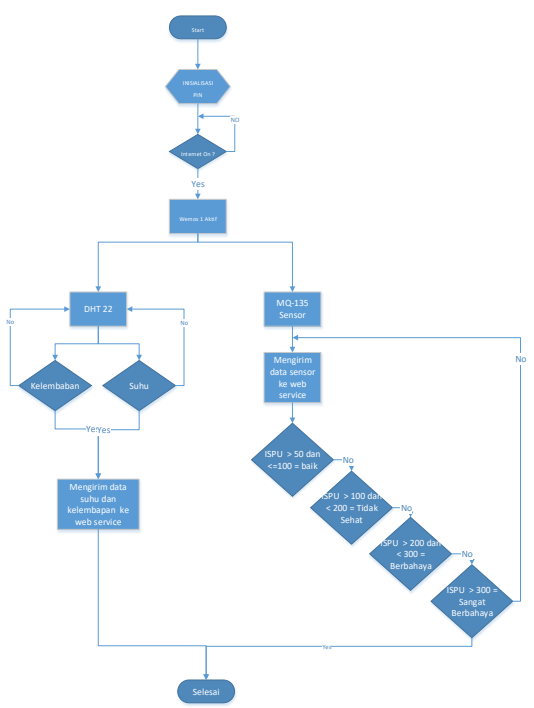

Gambar 3.5 Flowchart Perancangan Software Wemos 1

Dapat dilihat dari gambar diatas bahwa wemos 1 terdiri dari sensor DHT 22 dan MQ - 135, dimulai dengan menginisialisasikan pin pin yang tertanam lalu setelah itu aktif, dan merambah sampai kebawah mengaktifkan sistem sampai selesai.

Untuk perancangan sofware wemos 2 dapat dilihat dengan gambar dibawah ini.

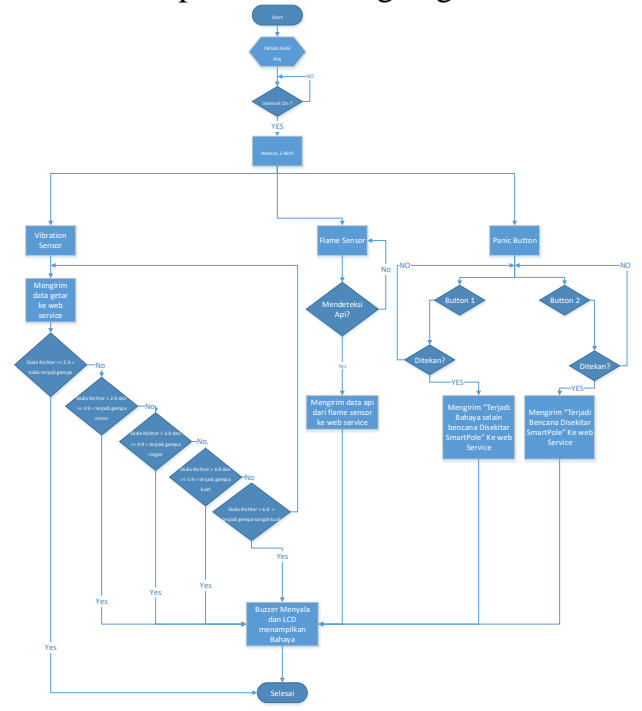

Gambar 3.6 Flowchart Perancangan Software Wemos 2

Perancangan software pada rangkaian yang terintegrasi dengan wemos D1 R2 2 merupakan program untuk sistem yang berjalan pada sistem darurat. Dimulai dengan mengisialisasi masing-masing pin yang terhubung dengan wemos D1 R2. Kemudian program akan mengecek koneksi wemos D1 R2 dengan internet. Jika sudah terkoneksi maka sistem akan aktif, jika tidak maka program akan kembali mengecek koneksi internet. Setelah sistem aktif maka program akan menyalakan keseluruhan sensor. Jika ada sesuatu bahaya maka program akan mengirim data ke web service, menampilkannya di LCD dan buzzer berbunyi.

Ketiga yaitu perancangan software pada arduino uno yang dapat memproses LDR pada lampu tiang early 
warning system.

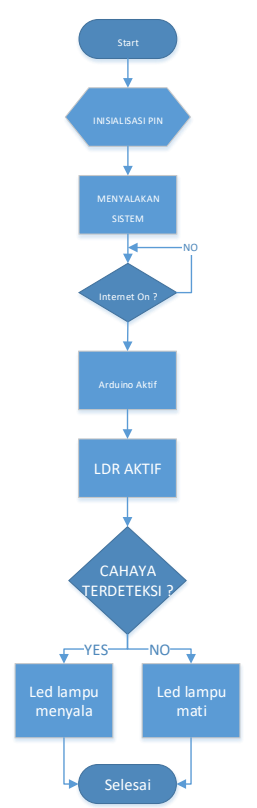

Gambar 3.7 Flowchart Perancangan Software Arduino UNO R3

Dan terakhir yaitu desain software atau Perancangan perangkat lunak pada raspberry ini berupa perancangan instalasi sistem operasi yang akan digunakan pada raspberry pi. Skema peracangan raspberry pi adalah seperti pada gambar 3.13 dibawah ini

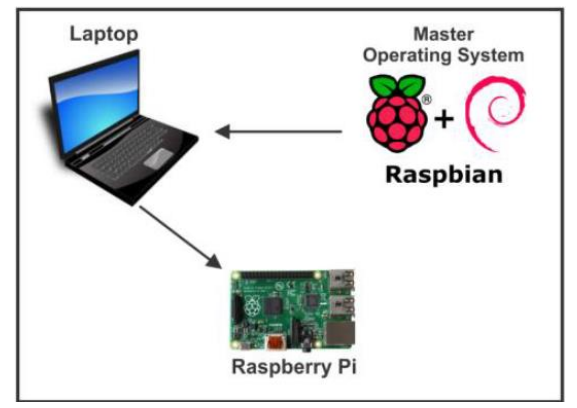

Gambar 3. 8 Skema perancangan instalasi Raspberry Py

Pada raspberry pi. Untuk peracangan instalasi sistem operasi terdapat beberapa komponen yang harus ada yaitu master operating system atau software sistem operasi yang akan di install di raspberry pi, yaitu Raspbian (Raspbery Debian) yang merupakan keluarga dari sistem operasi Linux khusus untuk raspberry. Laptop atau PC untuk melakukan instalasi dan raspberrynya. Instalasi akan dilakukan di laptop atau PC yang telah terhubung menggunakan kabel dengan raspberry pi. Untuk media penyimpanan data pada raspberry pi menggunakan micro SD dengan kapasitas minimal 4GB . sehingga instalasi akan disimpan didalam micro SD tersebut.

\subsection{Pengujian}

Langkah yang dilakukan pada tahapan ini adalah menguji sistem dari hasil rancangan yang sudah dibangun berdasarkan pengujian sistem secara keseluruhan.

3.4 Implementasi

Tahap implementasi yaitu sebagai bahan pembelajaran sehingga dapat mengetahui kekurangan dan kelebihan dari prototype early warning system ini yang telah dibangun oleh penulis.

\section{Hasil dan Pembahasan}

Hasil penelitian dapat dijelaskan pada tabel hasil pengujian dan implementasi atau sistem yang telah dibangun.

4.1 Pengujian 
Pengujian sistem secara keseluruhan ini menggunakan pengujian Blackbox, dilakukan dengan beberapa kasus uji dengan skenario yang ditentukan serta diharapkan mendapatkan hasil yang sesuai. Berikut adalah hasil dari pengujian blackbox pada prototype early warning system.

Tabel 1 Pengujian secara keseluruhan

\begin{tabular}{|c|c|c|c|c|}
\hline \multirow[t]{2}{*}{ Kasus Uji } & \multirow[t]{2}{*}{ Skenario } & \multirow[t]{2}{*}{ Hasil Yang Diharapkan } & \multicolumn{2}{|c|}{ Ketercapaian } \\
\hline & & & Ya & Tidak \\
\hline \multirow[t]{3}{*}{$\begin{array}{l}\text { Menghubun } \\
\text { gkan Ke } \\
\text { Internet }\end{array}$} & $\begin{array}{l}\text { Menyalakan Wemos } 1 \\
\text { dan modem } \mathrm{WiFi}\end{array}$ & $\begin{array}{l}\text { Pada layar serial monitor di Arduino IDE } \\
\text { menampilkan wemos terhubung ke WiFi } \\
\text { dan sensor menyala }\end{array}$ & $\checkmark$ & \\
\hline & $\begin{array}{l}\text { Menyalakan Wemos } 2 \\
\text { dan modem WiFi }\end{array}$ & $\begin{array}{l}\text { Pada layar serial monitor di Arduino IDE } \\
\text { menampilkan wemos terhubung ke WiFi } \\
\text { dan LED display menampilkan teks smart } \\
\text { pole system }\end{array}$ & $\mathbf{v}$ & \\
\hline & $\begin{array}{l}\text { Mematikan Wemos } 1 \text { dan } \\
2 \text { serta modem WiFi }\end{array}$ & $\begin{array}{l}\text { LED display tidak menampilkan apa - apa } \\
\text { dan sensor tidak menyala. }\end{array}$ & $\checkmark$ & \\
\hline \multirow{2}{*}{$\begin{array}{l}\text { Mengaktifka } \\
\mathrm{n} \quad \text { sensor } \\
\text { DHT22 }\end{array}$} & \multirow[b]{2}{*}{$\begin{array}{l}\text { Menyalakan wemos } 1 \\
\text { dan modem WiFi }\end{array}$} & $\begin{array}{l}\text { Sensor DHT22 mampu membaca nilai } \\
\text { inputan suhu dari sekitar smart pole }\end{array}$ & $v$ & \\
\hline & & $\begin{array}{l}\text { Sensor DHT22 mampu membaca nilai } \\
\text { inputan kelembaban udara dari sekitar } \\
\text { smart pole }\end{array}$ & $\checkmark$ & \\
\hline $\begin{array}{l}\text { Mengaktifka } \\
\text { n sensor } \\
\text { MQ135 }\end{array}$ & $\begin{array}{l}\text { Menyalakan wemos } 1 \\
\text { dan modem } \mathrm{WiFi}\end{array}$ & $\begin{array}{l}\text { Sensor DHT22 mampu membaca nilai } \\
\text { inputan suhu dari sekitar smart pole. }\end{array}$ & $\checkmark$ & \\
\hline $\begin{array}{l}\text { Mengaktifka } \\
\mathrm{n} \quad \text { flame } \\
\text { sensor }\end{array}$ & $\begin{array}{l}\text { Menyalakan wemos } 2 \\
\text { dan modem WiFi }\end{array}$ & $\begin{array}{l}\text { Flame sensor mampu membaca nilai } \\
\text { panas api dari sekitar smart pole. }\end{array}$ & $\checkmark$ & \\
\hline $\begin{array}{l}\text { Mengaktifka } \\
\mathrm{n} \quad \text { vibration } \\
\text { sensor }\end{array}$ & $\begin{array}{l}\text { Menyalakan wemos } 2 \\
\text { dan modem WiFi }\end{array}$ & $\begin{array}{l}\text { Vibration sensor mampu membaca nilai } \\
\text { inputan getaran dari sekitar smart pole. }\end{array}$ & $\checkmark$ & \\
\hline \begin{tabular}{lr}
\multicolumn{2}{l}{ Mengaktifka } \\
$\mathrm{n}$ & sensor \\
LDR & \\
\end{tabular} & $\begin{array}{l}\text { Menyalakan Arduino } \\
\text { UNO R3 }\end{array}$ & $\begin{array}{l}\text { LDR mampu membaca nilai cahaya } \\
\text { matahari yang masuk }\end{array}$ & $\checkmark$ & \\
\hline \multirow{2}{*}{$\begin{array}{l}\text { Mengaktifka } \\
\mathrm{n} \quad \text { Panic } \\
\text { button }\end{array}$} & \multirow[b]{2}{*}{$\begin{array}{l}\text { Menyalakan wemos } 2 \\
\text { dan modem } \mathrm{WiFi}\end{array}$} & $\begin{array}{l}\text { Panic Button } 1 \text { mampu membaca aksi } \\
\text { tekan bencana di smart pole. }\end{array}$ & $\checkmark$ & \\
\hline & & $\begin{array}{l}\text { Panic Button } 2 \text { mampu membaca aksi } \\
\text { tekan kriminalitas di smart pole. }\end{array}$ & $\boldsymbol{v}$ & \\
\hline \multirow[t]{3}{*}{$\begin{array}{l}\text { Mengaktifka } \\
\text { n Buzzer dan } \\
\text { LED display } \\
\text { memberikan } \\
\text { Informasi } \\
\text { bahaya }\end{array}$} & $\begin{array}{l}\text { Menyalakan wemos } 2 \text {, } \\
\text { modem WiFi, dan flame } \\
\text { sensor dalam keadaan } \\
\text { terdeteksi api disekitar } \\
\text { smart pole }\end{array}$ & $\begin{array}{l}\text { Buzzer Berbunyi dan LED } \\
\text { menampilkan isplay } \\
\text { Kebakaran disekitar Smart Pole" }\end{array}$ & $\checkmark$ & \\
\hline & $\begin{array}{l}\text { Menyalakan wemos } 2 \text {, } \\
\text { modem WiFi, dan } \\
\text { vibration sensor dalam } \\
\text { keadaan terdeteksi gempa } \\
\text { dengan skala richter }>2.9 \\
\text { SR }\end{array}$ & $\begin{array}{l}\text { Buzzer Berbunyi } \\
\text { dan LED Display menampilkan informasi } \\
\text { "Terjadi gempa bumi dengan .... skala } \\
\text { richter" } \\
\text { *... diisi dengan nilai Skala Richter } \\
\text { yang diterima oleh sensor getar }\end{array}$ & $\checkmark$ & \\
\hline & $\begin{array}{l}\text { Menyalakan wemos } 2 \text { dan } \\
\text { modem wifi, kemudian } \\
\text { sensor panic button } 1\end{array}$ & Buzzer Berbunyi & $\checkmark$ & \\
\hline
\end{tabular}




\begin{tabular}{|c|c|c|c|c|}
\hline \multirow[t]{4}{*}{ Kasus Uji } & \multirow[t]{2}{*}{ Skenario } & \multirow[t]{2}{*}{ Hasil Yang Diharapkan } & \multicolumn{2}{|c|}{ Ketercapaian } \\
\hline & & & Ya & Tidak \\
\hline & $\begin{array}{l}\text { membaca } \\
\text { kriminalitas }\end{array}$ & $\begin{array}{l}\text { dan LED Display menampilkan informasi } \\
\text { "Terjadi kriminalitas disekitar smart } \\
\text { pole" }\end{array}$ & & \\
\hline & $\begin{array}{l}\text { Menyalakan wemos } 2 \text { dan } \\
\text { modem wifi, kemudian } \\
\text { sensor panic button } 2 \\
\text { membaca aksi bencana }\end{array}$ & $\begin{array}{l}\text { Buzzer Berbunyi dan LED Display } \\
\text { menampilkan informasi "Terjadi bencana } \\
\text { disekitar smart pole" }\end{array}$ & $\checkmark$ & \\
\hline \multirow[t]{7}{*}{$\begin{array}{l}\text { Mengirim ke } \\
\text { database } \\
\text { smart village }\end{array}$} & $\begin{array}{l}\text { Menyalakan wemos1 dan } \\
\text { modem wifi, kemudian } \\
\text { sensor DHT22 membaca } \\
\text { nilai suhu disekitar smart } \\
\text { pole }\end{array}$ & $\begin{array}{l}\text { Nilai suhu hasil deteksi DHT22 dapat } \\
\text { terkirim ke tabel suhu pada database } \\
\text { smart village }\end{array}$ & $\checkmark$ & \\
\hline & $\begin{array}{l}\text { Menyalakan wemos1 dan } \\
\text { modem wifi, kemudian } \\
\text { sensor DHT22 membaca } \\
\text { nilai kelembaban udara } \\
\text { disekitar smart pole }\end{array}$ & $\begin{array}{l}\text { Nilai kelembaban udara hasil deteksi } \\
\text { DHT22 dapat terkirim ke tabel } \\
\text { kelembaban udara pada database smart } \\
\text { village }\end{array}$ & $\checkmark$ & \\
\hline & $\begin{array}{l}\text { Menyalakan wemos1 dan } \\
\text { modem wifi, kemudian } \\
\text { sensor MQ135 membaca } \\
\text { nilai kualitas udara } \\
\text { disekitar smart pole }\end{array}$ & $\begin{array}{l}\text { Nilai kualitas udara hasil deteksi MQ135 } \\
\text { dapat terkirim ke tabel kualitas udara pada } \\
\text { database smart village }\end{array}$ & $\sqrt{ }$ & \\
\hline & $\begin{array}{l}\text { Menyalakan wemos } 2 \text { dan } \\
\text { modem wifi, kemudian } \\
\text { flame sensor membaca } \\
\text { apakah terdapat api } \\
\text { disekitar smart pole }\end{array}$ & $\begin{array}{l}\text { Hasil deteksi flame sensor dapat terkirim } \\
\text { ke tabel api pada database smart village }\end{array}$ & $\checkmark$ & \\
\hline & $\begin{array}{l}\text { Menyalakan wemos } 2 \text { dan } \\
\text { modem wifi, kemudian } \\
\text { vibration sensor } \\
\text { membaca apakah terdapat } \\
\text { getaran yang berpotensi } \\
\text { gempa disekitar smart } \\
\text { pole }\end{array}$ & $\begin{array}{l}\text { Hasil deteksi vibration sensor dapat } \\
\text { terkirim ke tabel gempa pada database } \\
\text { smart village }\end{array}$ & $\sqrt{ }$ & \\
\hline & $\begin{array}{l}\text { Menyalakan wemos } 2 \text { dan } \\
\text { modem wifi, kemudian } \\
\text { panic button } 1 \text { membaca } \\
\text { apakah terdapat aksi } \\
\text { kriminal disekitar smart } \\
\text { pole }\end{array}$ & $\begin{array}{l}\text { Hasil aksi pada panic button } 1 \text { dapat } \\
\text { terkirim ke tabel kriminalitas pada } \\
\text { database smart village }\end{array}$ & $\sqrt{ }$ & \\
\hline & $\begin{array}{l}\text { Menyalakan wemos } 2 \text { dan } \\
\text { modem wifi, kemudian } \\
\text { panic button } 2 \text { membaca } \\
\text { apakah terdapat aksi } \\
\text { bencana disekitar smart } \\
\text { pole }\end{array}$ & $\begin{array}{l}\text { Hasil aksi pada panic button } 2 \text { dapat } \\
\text { terkirim ke tabel bencana pada database } \\
\text { smart village }\end{array}$ & $\checkmark$ & \\
\hline $\begin{array}{l}\text { Mengaktifka } \\
\mathrm{n} \text { lampu } \\
\text { otomatis }\end{array}$ & $\begin{array}{l}\text { Menyalakan Arduino } \\
\text { UNO R3 dan nilai LDR } \\
\text { berada pada nilai }>400\end{array}$ & Lampu pada smart pole dapat menyala & $\sqrt{ }$ & \\
\hline $\begin{array}{l}\text { Mengaktifka } \\
\mathrm{n} \quad \text { camera } \\
\text { monitoring } \\
\text { system }\end{array}$ & $\begin{array}{l}\text { Menyalakan Raspberry } \\
\mathrm{Pi} \\
\text { Dan terkoneksi dengan } \\
\text { jaringan internet }\end{array}$ & $\begin{array}{l}\text { Output camera dapat terkirim ke } \\
\text { database dan dapat dilihat di web service }\end{array}$ & $\checkmark$ & \\
\hline
\end{tabular}


Perangkat keras yang dibuat berdasarkan perancangan yaitu prototype early warning system adalah sebagai berikut.

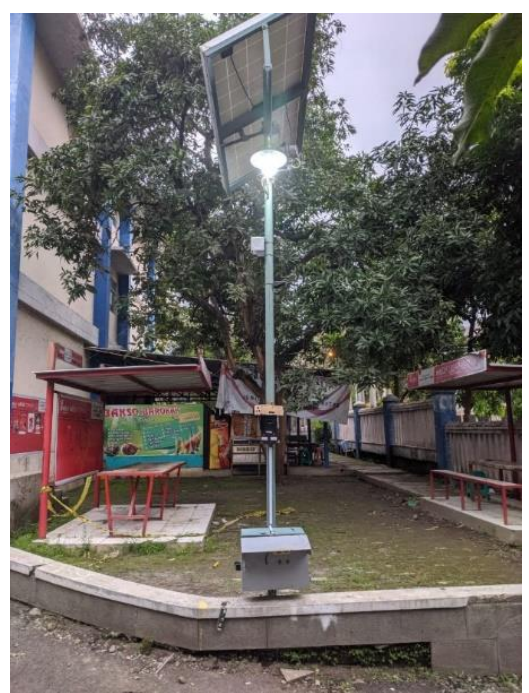

Gambar 4.1 Prototipe early warning system

\section{Kesimpulan}

Berdasarkan hasil pembahasan dan pengujian yang sudah dilakukan, maka kesimpulan dari penelitian ini dengan judul "Prototipe Smart Village berbasis Internet Of Things (Studi kasus early warning system)" yaitu sebagai berikut :

1. Sistem prototype early warning system yang dirancang menggunakan metode prototyping dengan menggunakan 3 embeded system, 3 embeded system tersebut diantara, Wemos D1 R2, Arduino UNO R3, dan Raspberry Pi sebagai pengontrol dari keselurah sistem pada prototoype early warning system. Dimana alat input yang diproses oleh wemos D1 R2 diantaranya, DHT22 sebagai pendeteksi suhu dan kelembaban udara disekitar, flame sensor sebagai pendeteksi kebakaran, vibration sensor sebagai pendeteksi gempa, dan panic button, digunakan sebagai keadaan darurat kriminalitas ataupun bencana yang tidak terdeteksi oleh sensor. Alat input yang diproses oleh Arduino UNO yaitu LDR sebagai landasan dalam lampu otomatis di prototype early warning system. Dan terakhir yaitu Raspberry Pi digunakan untuk memproses kamera monitoring disekitar tiang prototype early warning system.

2. Seluruh mikrokontroler yang digunakan (Wemos D1 R2, Arduino UNO R3, dan Raspberry Pi) dihubungkan dengan media transmisi data internet untuk terintegrasi dengan web service sehingga peralatan sensor akan mudah untuk dikontrol dan dimonitoring lewat internet dan memudahkan dalam perawatan peralatan sensor.

3. Cara kerja system prototype early warning system ini dimulai dari seluruh mikrokontroler diaktifkan lalu terhubung dengan jaringan internet yang tersedia, setelah itu DHT22 akan mendeteksi keadaan suhu disekitar dan keadaan kelembaban udara, MQ 135 akan mendeteksi kadar kulitas udara disekitar, flame sensor akan mendeteksi keadaan apakah adanya api atau tidak, viration sensor akan mendeteksi getaran gempa yang ada disekitar, panic button bekerja jika ada yang menekan tombol, dan kamera erfungsi untuk kamera keamanan yang disekitar tiang. Serta lampu otomatis yang befungsi secara otomatis.

\section{Daftar Pustaka}

[1] B. Orenzi, "Tentang BOC Indonesia," 03 februari 2019. [Online]. Available: https://www.boc.web.id/statistik-pengguna-digital-dan-internet-indonesia-2019/. [Diakses 12 juli 2019].

[2] BNPB, “Apa itu Sistem Peringatan Dini (Early Warning System),” 21 Maret 2018. [Online]. Available: https://bpbd.jakarta.go.id/article/detail/166. [Diakses 22 September 2019]. 
[3] BNPB, “Apa itu Sistem Peringatan Dini (Early Warning System),” 2 Maret 2018. [Online]. Available: https://bpbd.jakarta.go.id/article/detail/166. [Diakses 22 September 2019].

[4] Sujadi, Harun, Nunu Nurdiana, and Fahmi Nurbani. "RANCANG BANGUN PROTOTYPE SMART OFFICE SYSTEM BERBASIS IOT PADA BUILDING AUTOMATION SYSTEM." J-ENSITEC 5.02 (2019).

[5] BNPB, "Definisi dan Jenis Bencana," 13 Oktober 2017. [Online]. Available: https://bnpb.go.id/home/definisi. [Diakses 22 September 2019].

[6] Prasetyo, Tri Ferga, Abghi Firas Isdiana, and Harun Sujadi. "Implementasi Alat Pendeteksi Kadar Air pada Bahan Pangan Berbasis Internet Of Things." SMARTICS Journal 5.2 (2019): 81-96.

[7] Sujadi, Harun, Nunu Nurdiana, and Fahmi Nurbani. "RANCANG BANGUN PROTOTYPE SMART OFFICE SYSTEM BERBASIS IOT PADA BUILDING AUTOMATION SYSTEM." J-ENSITEC 5.02 (2019).

[8] D. Satria and H. Ahmadian, "Designing Home Security Monitoring System Based Internet of Things ( IoTs ) Model,” J. Serambi Eng., vol. III, no. 1, pp. 255-261, 2018.

[9] Zulfan, Bahagia, H. Ahmadian, and D. Satria, "SISTEM INFORMASI DATA KORBAN

KEBENCANAAN BERBASIS WEB,”Semin. Nas. II USM 2017, vol. 1, pp. 110-113, 2017. 